\title{
EFFECT OF SACCAHAROMYCES CEREVICIAE (INACTIVATED YEAST) ON QUAIL FED RATION CONTAMINATED WITH FUMONISIN B1 MYCOTOXICOSIS.
}

\author{
M.R. KHALIL; H.A. SHALABY and Z.A.A. KHADER
}

Animal Health Research Institute, Mansoura Laboratory.

\section{ABSTRACT}

Received at: 31/3/2013

Accepted: 11/5/2013
In this study, 160 day-old, Japanese quail chicks were randomly assigned into four groups, 40 birds of each. The first control group was fed on a basal diet (group1) and the other 3 groups were fed basal diet supplemented with $0.5 \%$ yeast, $0.5 \%$ yeast $+200 \mathrm{mg}$ fumincin-B1/ $\mathrm{kg}$ diet and 200mg fumincin-B1/ $\mathrm{kg}$ diet, respectively. The results of fumincin-B1(FBI) supplemented group showed a significant on increase in mortality rate, alanine amonotransferase (ALT), aspartate aminotransferase (AST), cholesterol, uric acid and createnine and a decrease in body weight, hatchability, fertility and hatching weight, hematological parameters, serum total proteins, globulins and glutathione peroxidase (GPx) activity in comparison with the control group. Yeast supplementation was found to alleviate the toxic effects of FB1.

Key Words: Fumonisin $B_{1} \bullet$ Japanese quail, Biochemical, Bloods, Yeast.

\section{INTRODUCTION}

Mycotoxins are secondary toxic metabolites of moulds and their negative effects on poultry production are difficult to overestimate. More than 300 mycotoxins have been shown to induce signs of toxicity in mammalian and avian species. It has been estimated that $25 \%$ of the world's crop production is contaminated with mycotoxins (Fink-Gremmels, 1999) and this number is increasing. These contaminants have a broad range of toxic effects, including carcinogenicity, immunotoxicity and neurotoxicity in addition to reproductive and developmental toxicity (Diana et al., 2006; Elaroussi et al., 2006 and 2008). The most important mycotoxins are aflatoxins, ochratoxin A, fumonisins, trichothecenes and zearalenone. (O'Brien and Dietrich, 2005; Butkeraitis et al., 2004, 2006 and Meissonier et al., 2007).

Fumonisin B-1 (FB-1) is a mycotoxin produced by Fusarium verticillioides, (Loiseau et al., 2007), Fusarium moniliforme-contaminated culture material has been shown to induce toxic responses, including increased mortality, reduced size of the bursa of Fabricius, thymus, and spleen, decreased body weight gain, myocardial degeneration, myocardial hemorrhage, alterations in the hemostatic mechanism, and necrosis of hepatocytes, when fed to chickens, ducklings, and turkey poults (Jeschke et al., 1987; Ogido et al., 2004 and Deshmukh et al., 2007).

Recently, yeast has been successfully used as an effective agent for counteracting aflatoxin or reducing aflatoxicosis in the small intestine (Stanley et al., 1993) and reducing ochratoxin in male broiler chicks (El-Barkouky, 2008). As well, improve the immune response of poultry (Santin et al., 2003). Yildirm and Parlat (2003) showed that, hatchability, fertility and embryonic mortality improved due to adding yeast into laying quail diets.

Therefore the current study aimed to investigate the effectiveness of yeast in countring the harmful effects of fumincin-B1 which was enriched in Japanese quail diets for 9 week of age via performance and physiological parameters.

\section{MATERIALS and METHODS}

A total number of 160 one day old, Japanese quail chicks, obtained from the farm of Biological Application Department, Nuclear Research Center at Inshas were used in the present study. The quail chicks were randomly assigned equally to four groups (40 birds per each). Each group contained 2 replicates of 20 birds. For 9 week experimental period, birds were kept in battery cages, water and feed was provided ad lib. A basal diet of $24 \%$ protein and 3000 kcal M.E. $/ \mathrm{kg}$ was formulated to cover all nutrients needed a according to N.R.C 1994, (Table 1). The experimental design was included four tested groups as follows:

1- Group(1): The basal diet and served as control

2- Group(2): The basal diet supplemented with $0.5 \%$ yeast.

3- Group(3): The basal diet supplemented with $0.5 \%$ yeast $+200 \mathrm{mg}$ fumincin-

$\mathrm{B} 1$ ( dissolved in distilled water) $/ \mathrm{kg}$ diet. 4- Group(4): The basal diet supplemented with $200 \mathrm{mg}$ fumincin $\mathrm{B} 1 / \mathrm{kg}$ diet. 


\section{Fumonisin production and analysis.}

Fusarium moniliforme culture material, containing FB1, was produced as previously described by Weibking et al. (1995). Culture were grown in sterilized 0.946 liter canning jars containing $100 \mathrm{~g}$ of whole shelled corn and $100 \mathrm{ml}$ of distilled water. A $5 \mathrm{ml}$ vial of lyophilized F.moniliforme M-1325, provided by the Fusarium Research Center (Pennsylvania State University Park,Pa.) was added to $500 \mathrm{ml}$ sterilized distilled water and $2 \mathrm{ml}$ of this suspension was added to the autoclaved jars. The jars were incubated in the dark in an open room for a total of $5 \mathrm{wk}$ at $27^{\circ} \mathrm{C}$.

Individual body weight, mortality rate and feed intake were recorded weekly. After sexual maturity at 6 week of old, 12 female and 6 male of each treatment were used. Egg production, fertility, hatchability, embryonic death and weight of hatching chicks were recorded up to 9 weeks of age.

At 6 week old, three birds of each replicate group (6 birds/ group) were randomly slaughtered. Carcass was eviscerated and some organs, including spleen, liver, heart, testes, oviducts and ovaries were removed and weighed individually then their weights were related to live body weight.

Two blood samples were collected during slaughtering the first one was collected with anticoagulant while the second sample was collected without anticoagulant to measure hematological parameters and some serum biochemical parameters. Hematological parameters:
Red and White blood cells count (RBC and WBC) were determined according to Natt and Herrick (1952). Hemoglobin concentration (Hb) was determined according to Dacie, and Lewis, (1991). Serum total protein according to Biuret method (Henery, 1964), albumin according to Drupt, (1976). Serum globulin was calculated by subtracting albumins from total protein. Cholesterol was estimated by using the method of Watson, (1960). Liver function tests: alanine amino transaminase (ALT) and aspartate amino transaminase (AST) were determined according to Reitman and Frankel (1957). $\alpha$-phetoprotein (AFP) was determined by radioimmunoassay (RIA) techniques, and used to estimate GPx activity (nmol/min/ml). Uric acid was determined according to James and White (1971) and Createnine was estimated by using the method of Husden and Ropaport (1968), calorimetrically by using commercial kits (bio Merieux - co., Marcyl Etoile - France).

Statistical analysis:

Data were analyzed statistically using the General Linear Models procedure of the program CoStat (1986). The ANOVA model was used according to Snedecor and Cochran (1982) to study the role of Sacchromyces Cervisiae in suppressing the effects of Fumincin mycotoxicosis in Japanese quail. The differences between averages were subjected to Duncan Multiple Range test for all variables (Duncan 1955).

Table 1: Composition and calculated analysis of the basal diets

\begin{tabular}{ll}
\hline Contents & Starter diet \% \\
\hline Ground yellow corn & 53.00 \\
Soybean meal $(44 \%)$ & 34.00 \\
Corn gluten meal $(60 \%)$ & 7.000 \\
Calcium carbonate & 1.400 \\
Dicalcium phosphate & 1.600 \\
Sodium chloride & 0.400 \\
Vegetable oil & 1.500 \\
L-Lysine-Hcl & 0.200 \\
DL-Methionine & 0.280 \\
Choline chloride & 0.240 \\
Premix* & 0.380 \\
\hline & 100.00 \\
Calculated analysis** & \\
Crude protein & 24.0 \\
ME & 3000 \\
Ca & 1.01 \\
Available P & 0.45 \\
Lysine & 1.37 \\
Methionine & 0.64 \\
Methionine + Cysteine & 1.11 \\
\hline
\end{tabular}

*Each kilogram of diet contains, A, 12000 I.U; D3, 2000 I.U; E, 10mg; K, 2mg; B1, 1mg; B6,1.5mg;B12, 10 10g; B2, 4mg;

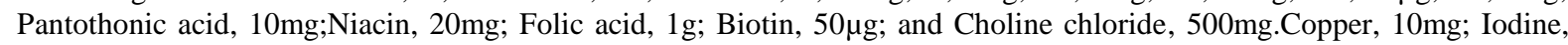
$1 \mathrm{mg}$; Iron, 30mg; Manganese, 55mg; Zing, 55mg and Selenium, $1 \mathrm{mg}$.

** Values were calculated according to the nutrient composition to the NRC (1994). 


\section{RESULTS}

Body weight, and Mortality rate:

Body weight of birds fed yeast supplemented diet (G2) was significantly higher than that of the control (Table 2) through the experimental periods. The group of birds received fumincin-diet (G4) recorded a significantly lower body weight than all treated groups. Mortality rate of fumincin-diet (G4) and fumincin-yeast group (G3) were higher than other treated groups (Fig 1).

Table 2: Effect of Sacchromyces Cervisiae (Yeast) and Fumonisin on Body weight (gm) in Japanese quail

\begin{tabular}{ccccc}
\hline Weeks & $\begin{array}{c}\text { G 1 } \\
\text { Control }\end{array}$ & $\begin{array}{c}\text { G 2 } \\
\text { Yeast }\end{array}$ & $\begin{array}{c}\text { G 3 } \\
\text { Yeast }+F-B 1\end{array}$ & $\begin{array}{c}\text { G 4 } \\
\text { F-B1 }\end{array}$ \\
\hline WK 1 & $21.46^{\mathrm{a}} \pm 0.46$ & $22.06^{\mathrm{a}} \pm 1.38$ & $19.48^{\mathrm{b}} \pm 0.49$ & $18.84^{\mathrm{c}} \pm 0.70$ \\
\hline WK 2 & $42.25^{\mathrm{b}} \pm 0.66$ & $47.06^{\mathrm{a}} \pm 1.22$ & $40.68^{\mathrm{c}} \pm 0.68$ & $35.56^{\mathrm{d}} \pm 1.47$ \\
\hline WK 3 & $80.44^{\mathrm{ab}} \pm 1.64$ & $86.35^{\mathrm{a}} \pm 2.38$ & $79.05^{\mathrm{bc}} \pm 1.79$ & $75.80^{\mathrm{c}} \pm 1.09$ \\
\hline WK 4 & $131.71^{\mathrm{b}} \pm 1.24$ & $136.10^{\mathrm{a}} \pm 2.13$ & $124.73^{\mathrm{c}} \pm 0.46$ & $122.89^{\mathrm{d}} \pm 1.19$ \\
\hline WK 5 & $174.38^{\mathrm{b}} \pm 3.90$ & $180.49^{\mathrm{a}} \pm 1.81$ & $161.43^{\mathrm{c}} \pm 3.08$ & $149.90^{\mathrm{d}} \pm 4.28$ \\
\hline WK 6 & $197.96^{\mathrm{ab}} \pm 1.58$ & $209.01^{\mathrm{a}} \pm 3.37$ & $190.59^{\mathrm{bc}} \pm 0.94$ & $182.28^{\mathrm{c}} \pm 1.51$ \\
\hline WK 7 & $243.60^{\mathrm{b}} \pm 8.10$ & $263.49^{\mathrm{a}} \pm 12.21$ & $221.26^{\mathrm{c}} \pm 7.40$ & $201.68^{\mathrm{d}} \pm 8.88$ \\
\hline
\end{tabular}

a, b, c Means within row with different superscripts are significantly different $(\mathrm{p}<0.05)$

Fig.(1) The effects of Yeast and Fumonisin on Mortality in Japanese quail

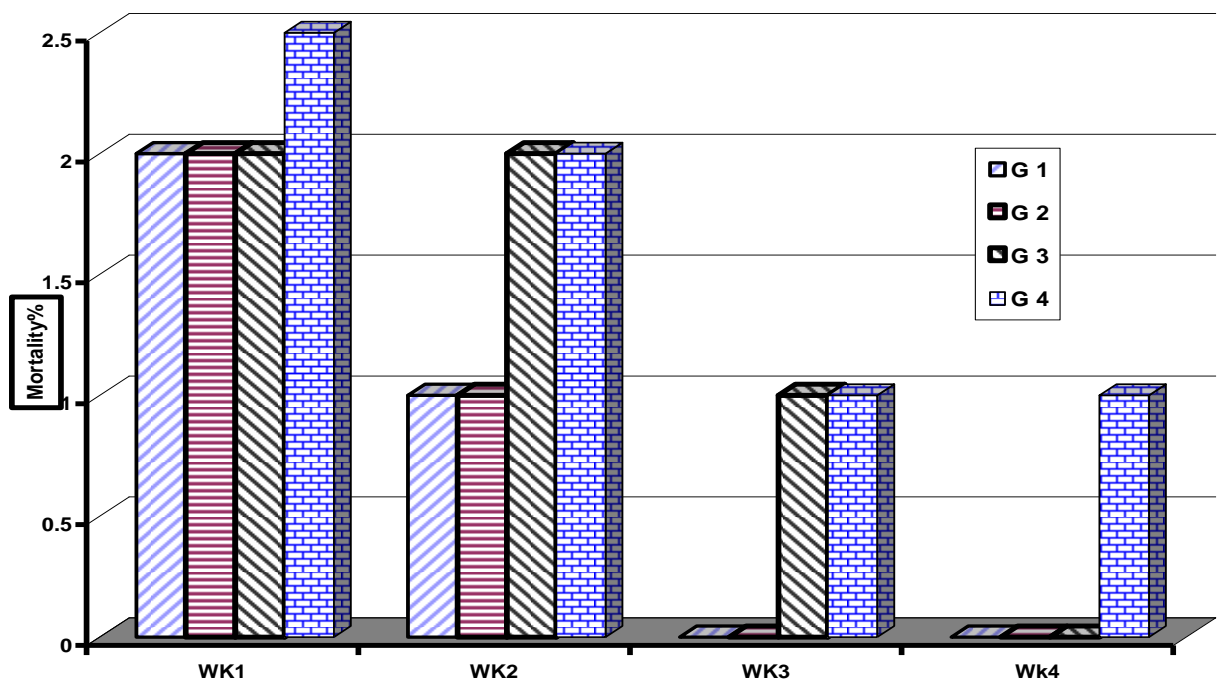

\section{Hatchability, Fertility and Hatching weight:}

It is clear that, addition of yeast into basal diet improved egg fertility and hatchability, in contrast enriched FB1 (G4) led to higher depression in both parameters, (Table 3). 
Table 3: Effect of Yeast and Fumonisin on Hatchability\%, Fertility \%, Infertility \% and Hatching weight (gm) in Japanese quail

\begin{tabular}{|c|c|c|c|c|c|}
\hline Weeks & Item & $\begin{array}{c}\text { G } 1 \\
\text { Control } \\
\end{array}$ & $\begin{array}{c}\text { G } 2 \\
\text { Yeast } \\
\end{array}$ & $\begin{array}{c}\text { G 3 } \\
\text { Yeast +F-B1 }\end{array}$ & $\begin{array}{c}\text { G } 4 \\
\text { F-B1 } \\
\end{array}$ \\
\hline \multirow{3}{*}{ WK 1} & Hatchability \% & 75 & 76.64 & $\mathbf{7 0 . 3 7}$ & 40 \\
\hline & Fertility \% & 79.41 & 93.10 & 78.50 & 66.70 \\
\hline & Hatching weight(gm) & $6.80^{\mathrm{a}} \pm 0.10$ & $6.81^{\mathrm{a}} \pm 0.21$ & $6.21^{b} \pm 0.09$ & $6.19^{b} \pm 0.10$ \\
\hline \multirow{3}{*}{ WK 2} & Hatchability \% & 77 & 79.3 & 76.92 & 58.33 \\
\hline & Fertility \% & 89.28 & 83.94 & 88.88 & 73.33 \\
\hline & Hatching weight(gm) & $8.66^{\mathrm{a}} \pm 0.11$ & $8.62^{a} \pm 0.09$ & $8.13^{b} \pm 0.14$ & $7.87^{\mathrm{c}} \pm 0.11$ \\
\hline \multirow{3}{*}{ WK 3} & Hatchability \% & 79.30 & 80.60 & 77.20 & 61.76 \\
\hline & Fertility \% & 90.3 & 96 & 89 & 72.8 \\
\hline & Hatching weight(gm) & $8.83^{a} \pm 0.14$ & $8.87^{a} \pm 0.13$ & $8.32^{b} \pm 0.10$ & $7.89^{c} \pm 0.12$ \\
\hline
\end{tabular}

${ }^{\mathrm{a}, \mathrm{b}, \mathrm{c}}$ Means within row with different superscripts are significantly different $(\mathrm{p}<0.05)$

\section{Egg production percentage:}

Egg production percentage of laying quails fed yeast (G2) was significantly higher than the control group (Figure2). Mean egg production \% were lower in birds fed Fumonisin (FB1) group 4.

Fig.(2): The effects of Yeast and Fumonisin B1 on Egg Production in Japanese Quail.

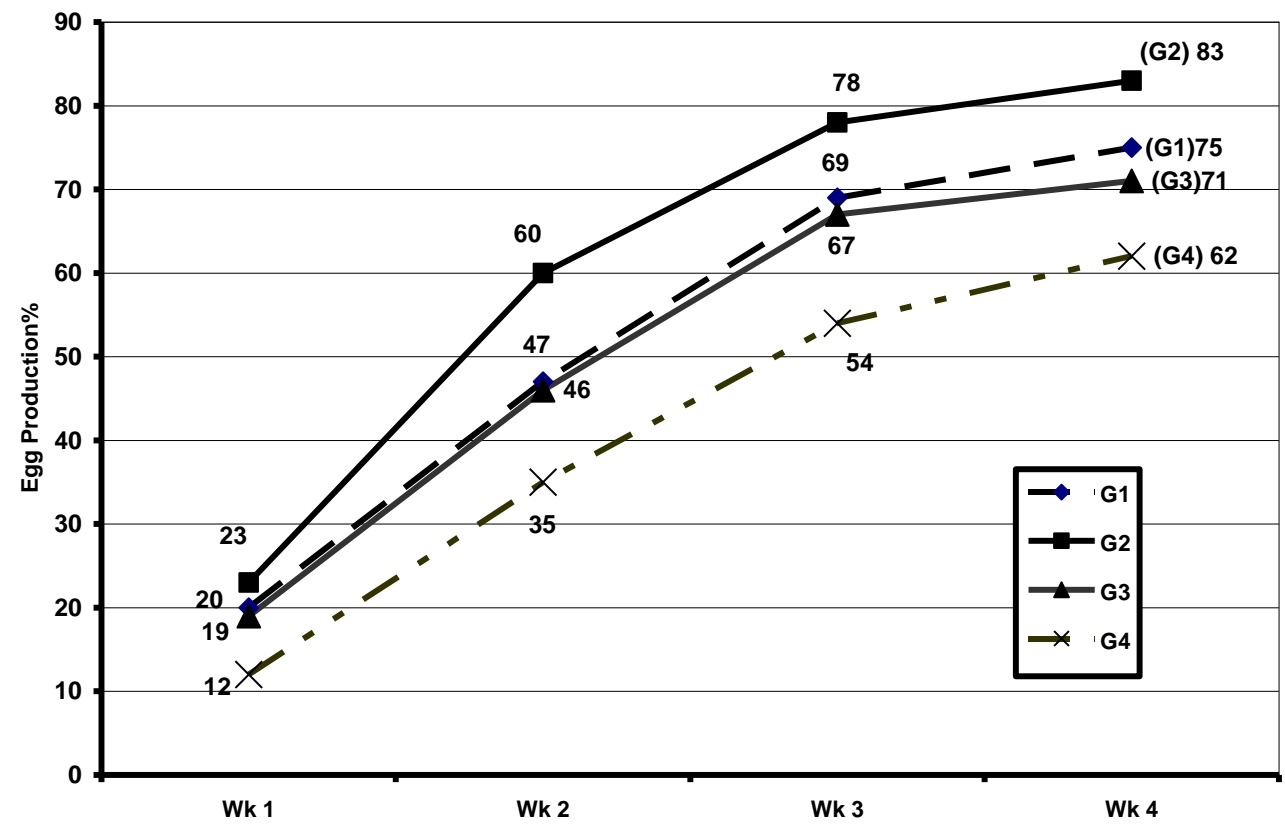




\section{Assiut Vet. Med. J. Vol. 59 No. 137 April 2013}

\section{Carcass aspects and internal organs.}

There are significant increases in carcass heart, spleen, testis and ovary in group 2 and significant decrease in group 4 (Table 4) compared to the control either in males or females. Relative weight of liver increases $(p<0.05)$ in the group G4 with fumincinB1 in comparison with the control.

Table 4: Effect of Sacchromyces Cervisiae (Yeast) and Fumonisin on Carcass weight and relative weights of some organs in Japanese quail

\begin{tabular}{|c|c|c|c|c|c|c|c|c|c|c|c|}
\hline \multirow[t]{2}{*}{ Groups } & \multicolumn{2}{|c|}{ Carcass } & \multicolumn{2}{|c|}{ Liver } & \multicolumn{2}{|c|}{ Heart } & \multicolumn{2}{|c|}{ Spleen } & \multirow[t]{2}{*}{ Testis } & \multirow[t]{2}{*}{ ovary } & \multirow[t]{2}{*}{ Oviduct } \\
\hline & 우 & $\hat{\sigma}$ & 우 & $\hat{\sigma}$ & 우 & $\hat{0}$ & 우 & $\hat{0}$ & & & \\
\hline $\begin{array}{c}\text { G } 1 \\
\text { control }\end{array}$ & $\begin{array}{c}64.68^{b} \\
\pm 1.16\end{array}$ & $\begin{array}{c}74.06^{\mathrm{a}} \\
\pm 0.78\end{array}$ & $\begin{array}{r}3.86^{\mathrm{c}} \\
\pm 0.12\end{array}$ & $\begin{array}{r}2.34^{\mathrm{c}} \\
\pm 0.19\end{array}$ & $\begin{array}{r}1.35^{\mathrm{a}} \\
\pm 0.45\end{array}$ & $\begin{array}{c}0.75 \\
\pm 0.10\end{array}$ & $\begin{array}{c}\mathbf{0 . 0 8 0}^{\mathrm{b}} \\
\pm \mathbf{0 . 0 0 7}\end{array}$ & $\begin{array}{c}0.090^{\mathrm{a}} \\
\pm 0.007\end{array}$ & $\begin{array}{r}2.47^{\mathrm{a}} \\
\pm 0.28\end{array}$ & $\begin{array}{l}2.21^{b} \\
\pm 0.26\end{array}$ & $\begin{array}{l}2.42^{b} \\
\pm 0.06\end{array}$ \\
\hline $\begin{array}{c}\text { G2 } \\
\text { Yeast }\end{array}$ & $\begin{array}{l}68.38^{\mathrm{a}} \\
\pm 1.27\end{array}$ & $\begin{array}{l}\mathbf{7 5 . 7 1} 1^{\mathrm{a}} \\
\pm 0.07\end{array}$ & $\begin{array}{l}3.11^{\mathrm{d}} \\
\pm 0.09\end{array}$ & $\begin{array}{r}2.45^{\mathrm{c}} \\
\pm 0.04\end{array}$ & $\begin{array}{r}1.24^{\mathrm{a}} \\
\pm 0.33\end{array}$ & $\begin{array}{c}0.92 \\
\pm 0.04\end{array}$ & $\begin{array}{l}0.102^{\mathrm{a}} \\
\pm \mathbf{0 . 0 1}\end{array}$ & $\begin{array}{r}0.093^{\mathrm{a}} \\
\pm 0.005\end{array}$ & $\begin{array}{r}2.49^{\mathrm{a}} \\
\pm 0.14\end{array}$ & $\begin{array}{r}2.61^{\mathrm{a}} \\
\pm 0.06\end{array}$ & $\begin{array}{l}2.34^{b} \\
\pm 0.20\end{array}$ \\
\hline $\begin{array}{c}\text { G } 3 \\
\text { Yeast+FB1 }\end{array}$ & $\begin{array}{c}64.24^{b} \\
\pm 0.83\end{array}$ & $\begin{array}{c}73.39^{\mathrm{b}} \\
\pm 1.05\end{array}$ & $\begin{array}{l}3.99^{\mathrm{b}} \\
\pm 0.11\end{array}$ & $\begin{array}{r}2.70^{b} \\
\pm 0.27\end{array}$ & $\begin{array}{l}0.76^{b} \\
\pm 0.11\end{array}$ & $\begin{array}{c}0.71 \\
\pm 0.09\end{array}$ & $\begin{array}{c}\mathbf{0 . 0 8 0}^{\mathrm{b}} \\
\pm 0.004\end{array}$ & $\begin{array}{c}0.074^{b} \\
\pm 0.005\end{array}$ & $\begin{array}{r}2.39^{b} \\
\pm 0.02\end{array}$ & $\begin{array}{r}1.72^{\mathrm{c}} \\
\pm 0.13\end{array}$ & $\begin{array}{r}2.79^{\mathrm{a}} \\
\pm 0.04\end{array}$ \\
\hline $\begin{array}{l}\text { G } 4 \\
\text { FB1 }\end{array}$ & $\begin{array}{l}61.65^{\mathrm{c}} \\
\pm 0.46\end{array}$ & $\begin{array}{l}72.99^{c} \\
\pm 0.15\end{array}$ & $\begin{array}{r}4.16^{\mathrm{a}} \\
\pm 0.19\end{array}$ & $\begin{array}{l}3.02^{\mathrm{a}} \\
\pm 0.01\end{array}$ & $\begin{array}{l}0.64^{b} \\
\pm 0.03\end{array}$ & $\begin{array}{c}\text { 0.89 } \\
\pm 7.07\end{array}$ & $\begin{array}{c}0.074^{b} \\
\pm 0.004\end{array}$ & $\begin{array}{l}0.060^{\mathrm{c}} \\
\pm 0.006\end{array}$ & $\begin{array}{r}1.95^{\mathrm{c}} \\
\pm 0.02\end{array}$ & $\begin{array}{l}1.01^{\mathrm{d}} \\
\pm 0.18\end{array}$ & $\begin{array}{c}0.81^{c} \\
\pm 0.09\end{array}$ \\
\hline
\end{tabular}

${ }^{a, b, c}$ Means within row with different superscripts are significantly different $(\mathrm{p}<0.05)$

\section{Some Blood parameters:-}

Hematological and Proteins Parameters of the different groups are presented in Table (5). The Red blood cells count, white blood cells count (WBCs) and Hemoglobin value are increased significantly due to adding yeast into diets than control. Also mean values of hemoglobin, white blood cells count, and total erythrocyte count were slightly higher in birds fed FB1. At the same table, the results obtained for total proteins, albumin, globulins and A / G ratio (Table 5) indicated that adding yeast (G2) to the basal diet resulted in a significant increase in total proteins and globulins. G3 come next to G2 in increasing total proteins and globulins, while the control group (G1) showed the significant decrease slightly values. While G4 was increased slightly in quails fed FB 1 than control. Also tables (5) shows significant increase in ALT, AST, cholesterol, uric acid, createnine and alpha feto protein (AFP) and decrease in GPx activity in quails received fumonisin (G4) in comparison with the control group one (G1) and all treatments.

Table 5: Effect of Sacchromyces Cervisiae (Yeast) and Fumonisin B1 on Some Biochemical Parameters in Japanese quail

\begin{tabular}{|c|c|c|c|c|c|c|c|c|c|c|c|c|}
\hline Groups & $\begin{array}{c}\text { RBCs } \\
\left(-\mathrm{xmm}^{6}\right)\end{array}$ & $\begin{array}{l}\text { WBCs } \\
\left(-\mathrm{xmm}^{3}\right)\end{array}$ & $\begin{array}{c}\text { Hb } \\
(\mathrm{g} / \mathrm{dl})\end{array}$ & $\begin{array}{c}\text { Total } \\
\text { Protein } \\
(\mathrm{g} / \mathrm{dl})\end{array}$ & $\begin{array}{c}\text { Albumin } \\
\text { (g/dl) }\end{array}$ & $\begin{array}{c}\text { Globulin } \\
\text { (g/dl) }\end{array}$ & $\begin{array}{c}\mathbf{A L T} \\
(\mathbf{u} / \mathbf{I})\end{array}$ & $\begin{array}{c}\text { AST } \\
(\mathbf{u} / \mathbf{I})\end{array}$ & $\begin{array}{c}\text { uric acid } \\
\text { (mg/dl) }\end{array}$ & $\begin{array}{c}\text { Createnine } \\
(\mathbf{m g} / \mathrm{dl})\end{array}$ & $\begin{array}{c}\text { Cholesterol } \\
\text { (g/dl) }\end{array}$ & $\begin{array}{c}\text { GPx } \\
\text { activity } \\
(\mathbf{n m o l} / \\
\text { min/m)l }\end{array}$ \\
\hline $\begin{array}{c}\text { G } 1 \\
\text { control }\end{array}$ & $\begin{array}{l}3.49^{b} \\
\pm 0.20\end{array}$ & $\begin{array}{l}16.1^{\mathrm{c}} \\
\pm 0.74\end{array}$ & $\begin{array}{l}11.14^{\mathrm{b}} \\
\pm 0.40\end{array}$ & $\begin{array}{l}4.06^{b} \\
\pm 0.21\end{array}$ & $\begin{array}{l}1.75 \\
\pm 0.12\end{array}$ & $\begin{array}{l}2.31^{\text {ab }} \\
\pm 0.19\end{array}$ & $\begin{array}{l}10.24^{\mathrm{bc}} \\
\pm 1.32\end{array}$ & $\begin{array}{l}25.38^{c} \\
\pm 0.87\end{array}$ & $\begin{array}{l}3.72^{\mathrm{bc}} \\
\pm 0.08\end{array}$ & $\begin{array}{l}0.47^{\mathrm{c}} \\
\pm 0.12\end{array}$ & $\begin{array}{r}125.4^{b} \\
\pm 1.67\end{array}$ & $\begin{array}{c}74.20^{b} \\
\pm 9.41\end{array}$ \\
\hline $\begin{array}{c}\text { G2 } \\
\text { Yeast }\end{array}$ & $\begin{array}{l}4.12^{\mathrm{a}} \\
\pm 0.39\end{array}$ & $\begin{array}{r}20.24^{\mathrm{a}} \\
\pm 0.67\end{array}$ & $\begin{array}{r}13.2^{\mathrm{a}} \\
\pm 1.39\end{array}$ & $\begin{array}{l}4.78^{\mathrm{a}} \\
\pm 0.19\end{array}$ & $\begin{array}{l}1.69 \\
\pm 0.15\end{array}$ & $\begin{array}{r}2.99^{\mathrm{a}} \\
\pm 0.28\end{array}$ & $\begin{array}{r}9.42^{\mathrm{c}} \\
\pm 0.58\end{array}$ & $\begin{array}{l}24.20^{c} \\
\pm 0.83\end{array}$ & $\begin{array}{r}3.50^{c} \\
\pm 0.22\end{array}$ & $\begin{array}{l}0.46^{\mathrm{c}} \\
\pm 0.11\end{array}$ & $\begin{array}{r}123.6^{\mathrm{bc}} \\
\pm 2.23\end{array}$ & $\begin{array}{r}98.00^{\mathrm{a}} \\
\pm 9.56\end{array}$ \\
\hline $\begin{array}{l}\text { G } 3 \text { FB1 } \\
+ \text { Yeast }\end{array}$ & $\begin{array}{r}3.94^{\mathrm{ab}} \\
\pm 0.28\end{array}$ & $\begin{array}{l}17.2^{b} \\
\pm 0.72\end{array}$ & $\begin{array}{l}11.98^{\text {ab }} \\
\pm 0.74\end{array}$ & $\begin{array}{l}4.68^{\mathrm{a}} \\
\pm 0.15\end{array}$ & $\begin{array}{l}1.78 \\
\pm 0.13\end{array}$ & $\begin{array}{r}3.00^{\mathrm{a}} \\
\pm 0.26\end{array}$ & $\begin{array}{l}11.22^{b} \\
\pm 0.67\end{array}$ & $\begin{array}{l}27.20^{\mathrm{a}} \\
\pm 2.16\end{array}$ & $\begin{array}{r}3.80^{b} \\
\pm 0.25\end{array}$ & $\begin{array}{l}0.79^{b} \\
\pm 0.15\end{array}$ & $\begin{array}{r}127.6^{\mathrm{a}} \\
\pm 1.14\end{array}$ & $\begin{array}{l}59.38^{c} \\
\pm 5.82\end{array}$ \\
\hline $\begin{array}{l}\text { G } 4 \\
\text { FB1 }\end{array}$ & $\begin{array}{l}3.50^{b} \\
\pm 0.22\end{array}$ & $\begin{array}{c}16.52^{\mathrm{bc}} \\
\pm 0.39\end{array}$ & $\begin{array}{l}11.70^{\text {ab }} \\
\pm 0.99\end{array}$ & $\begin{array}{c}4.18^{\text {ab }} \\
\pm 0.14\end{array}$ & $\begin{array}{l}1.44 \\
\pm 0.37\end{array}$ & $\begin{array}{l}2.74^{\text {ab }} \\
\pm 0.26\end{array}$ & $\begin{array}{l}12.58^{\mathrm{a}} \\
\pm 0.91\end{array}$ & $\begin{array}{l}30.60^{\mathrm{a}} \\
\pm 2.70\end{array}$ & $\begin{array}{l}4.43^{\mathrm{a}} \\
\pm 0.22\end{array}$ & $\begin{array}{l}1.07^{\mathrm{a}} \\
\pm 0.17\end{array}$ & $\begin{array}{l}129.6^{\mathrm{a}} \\
\pm 2.07\end{array}$ & $\begin{array}{c}34.20^{\mathrm{d}} \\
\pm 3.89\end{array}$ \\
\hline
\end{tabular}

a, b, c Means within row with different superscripts are significantly different $(\mathrm{p}<0.05)$ 


\section{DISCUSSION}

\section{Body weight, and Mortality rate:}

In the present study showed that body weight of birds fed yeast supplemented diet was significantly higher than that of the control through the experimental periods. The group of birds received fumincin-diet recorded a significantly lower body weight than all treated groups. Mortality rate of fumincin-diet and fumincin-yeast group were higher than other treated groups.

These results were expected due to role of mycotoxin FB1 (higher than $100 \mathrm{mg} / \mathrm{kg}$ diet) in depressing body weight gain of chicks (Brown et al., 1992; and Henry et al., 2000). Furthermore, Asroni et al. (2006); Elbarkouky, (2008); Girish and Smith, (2008) and Sharma et al. (2008) observed a reduction in body weight gain of Japanese quails fed fumincin-B1 diet.

Javed et al. (1993) observed an increase in mortality rate of broilers fed FB1-supplemented diets. The beneficial effect of yeast in countering the harmful action of fumincin-B1 has been reported by AbdelAzeem et al. (2005). In addition Stanley et al. (1993) and Abu-Taleb et al. (2007a) related the beneficial role of yeast due to its structure of cell wall which adsorbed mycotoxin preventing its adverse effect.

\section{Hatchability, Fertility and Hatching weight:}

It is clear that, addition of yeast into basal diet improved egg fertility and hatchability, in contrast enriched FB1 led to higher depression in both parameters. The presence of yeast inherent Fumonisin enriched diet success to improve fertility, hatchability of quails than those fed FB1 alone. Yildirm and Parlat (2003) showed that, hatchability, fertility and embryonic mortality are improved due to adding yeast into Japanese quail diets.

\section{Egg production percentage:}

Egg production percentage of laying quails fed yeast was significantly higher than the control group. Mean egg production \% were lower in birds fed Fumonisin (FB1) group. The improvement in laying performance may be due to the decreasing effect of yeast on pathogenic bacteria, Kim et al. (2002) and Park et al. (2002). Soliman (2003) stated that, including live yeast to laying diets improved egg production and laying performance.

\section{Carcass aspects and internal organs.}

The quail chicks fed diets with yeast showed significant increases in carcass and relative wights of heart, spleen, testis and ovary and significant decrease in fed diet contaminated with fumincin B1when compared with the control either in males or females. Relative weight of liver increases $(p<0.05)$ in the group $\mathrm{G} 4$ with fumincinB1 in comparison with the control. Fusarium moniliforme-contaminated culture material has been shown to induce toxic action, including increased mortality, reduced size of the bursa of Fabricius, thymus, and spleen, (Ogido et al., 2004 and Deshmukh et al., 2007). On the other hand, live yeast, Sacchromyces cerevisiae, was found to alleviate the adverse effects of mycotoxins in poultry (Abu Taleb et al., 2007b).

\section{Some Blood parameters:-}

The Red blood cells count, white blood cells count (WBCs) and Hemoglobin value are increased significantly due to adding yeast into diets than control. Similar results were recorded by Wakwak et al. (2003) who observed an increase in WBCs of growing quails fed diets with live yeast. The increment in indicated that, adding yeast into laying quail diets may improve immunity system. Santin et al. (2003) reported that the immune response of birds improved by adding yeast into diets. G4 was increase slightly in quails fed FB 1 than control. Mean values of hemoglobin, white blood cells count, and total erythrocyte count were slightly higher in birds fed FB1. Total leukocyte counts were higher in FB1-fed group because of an increase in the number of heterophils and lymphocytes, Deshmukh et al. (2007) and Sharma et al. (2008).

The above mentioned results in this study showed that a significant increase in total proteins and globulins in yeast treated group $(\mathrm{G} 2)$. While G3 come next to G2 in increasing total proteins and globulins, but the control group (G1) showed the significant decrease slightly values. While G4 was increased slightly in quails fed FB 1 than control. Some authors reported that Japanese quail (Abdel-Azeem et al., 2005), and broiler chicks (Tollba et al., 2004), showed significant increases in the values of total proteins and globulins as the result of feeding Yeast. Sharma et al. (2008). Showed that total serum proteins, albumin and globulins values were higher in all treatment groups of birds fed FB1 compared with the control group.

The significant increases in ALT, AST, cholesterol, uric acid, createnine and alpha feto protein (AFP) and decrease in GPx activity in quails received fumonisin (G4) in comparison with the control group one (G1) and all treatments. Yeast observed partial improves the parameters in group three (G3). The previous results agree with those of Sharma, et.al.,(2008) they reported that birds fed $\mathrm{FB}_{1}$ showed higher values of cholesterol, aspartate transaminase, lactate dehydrogenase, and creatine kinase than that of the control group. 
Glutathione is probably the most abundant natural low molecular weight thiol that is detected in virtually all living cells. It plays a central role in transporting amino acids across cell membranes, catalyzing disulfide exchange reactions, and serving as coenzymes for certain enzymes, detoxifying free radicals and acting as reactive intermediates (Sen and Packer, 1996 and Mohamed, 2000). The liver appears to be a vast reservoir for GSH, it releases from the hepatocytes into bile and blood where it turns over rapidly to be available to other organs (Kaplowitz et al., 1994).

\section{REFERENCES}

Abdel-Azeem, F.; Nematallah, G.M. Ali and Faten, A.A. Ibrahim, (2005): Digeston, neomycin and yeast supplementation in broiler diets under Egyptian summer conditions.Egypt. Poult. Sci., 25: 11: 497-525.

Abu Taleb, A.M.; Ayyoub, S.M.; EL-Barkouky, E.E. and EL-Kolaly, M.T. (2007a): Radioiodination of Ochratoxin to Study the Role of Yeast in Counterating its Effect on Japanese Quail. Isotope \& Rad. Res., 39, (4): 943-953.

Abu Taleb, A.M.; El-Barkouky, E.E. and Saleh, H.M. (2007b): The Use of Mannan-oligosaccharide to suppress the Toxic Effect of Ochratoxin in Male Broilers. Egyptian J. Nutrition and Feeds. 10(2): 557-581.

Asroni, P.K.; Kotoch, Rc.; Gupto, VK.; Deshmukh, S.; Jindal, N.; Ledoux, DR.; Rottinghous, GE. and Singh, SP. (2006): Effect of feeding fusarium verticillioides (formerly fusorium monifiorme).culture material containing known levels of fumonsin B1 in Japanese quail (Coturnix coturnix Japonica). Poultry Sci. 85(7): 1129-1135.

Brown, T.P.; Rottinghaus, G.E. and Williams, M.E. (1992): Fumonisin mycotoxicosis in broilers: Performance and pathology. Avian Dis. 36: 450-454.

Butkeraitis, P.; Oliveira, CA.; Ledoux, DR.; Ogido, R.; Albuquerque, R.; Rosmaninho, JF. and Rottinghaus, GE. (2004): Effect of dietary fumonisin B1 on laying Japanese quail. $\mathrm{Br}$ Poult Sci. Dec; 45(6): 798-801.

Butkeraitis, P.; Oliveira, C.A.F.; Ledoux, D.R. and Rottinghaus, GE. (2006): Effect of fumonisin B1 on Hematology and Serum Biochemistry of laying Japanese quail. J. Poult Sci. 43: (6): 301-306.

CoStat 3.03 .Copyright (1986): CoHort Software. AIL rights reserved. P.O. Box 1149, Berkeley, CA 94701.

Dacie, J.V. and Lewis, S.M. (1991): Practical hematology. $7^{\text {th }}$ Ed. Churchill living stone. PP. 37, 38, 39, 48 .
Deshmukh, S.; Asrani, RK.; Ledoux, DR.; Rottinghaus, GE.; Bermudez, AJ. and Gupta, $V K$. (2007): Pathologic changes in extrahepatic organs and agglutinin response to Salmonella Gallinarum infection in Japanese quail fed Fusarium verticillioides culture material containing known levels of fumonisin B1. Avian Dis. Sep;51(3):705-12.

Diana, R.; Abalo, C.; Yves-Jacques, S. and Yvan, L. (2006): Toxicokinetics and toxicodynamics of ochratoxin A, an update. Chemico-Biological Interactions. Volume 159, Issue 1, 5 January, Pages 18-46.

Drupt, F. (1976): Colorimetric method for determination of albumin. Phar. Bio. Vol. (9). ToneVIII. 777.

Duncan, D.B. (1955): Multiple range and multiple Ftest. Biocmetrics, 11: 1-42.

Elaroussi, MA.; Mohamed, ER.; El Barkouky, KM.; Atta, A.M.; Abdou, AM. and Hatab, M.H. (2006). Experimental Ochratoxin in broiler chickens. Avian Pathology (August) 35(4), 263-269.

Elaroussi,. MA.; ER.; Mohamed, F.R.; Elgendy, M.S.; El Barkouky, KM.; Abdou, A.M. and Hatab, M.H. (2008). Ochratoxicosis in Broiler Chickens: Functional and Histological changes in Target Organs. International Journal of Poultry Science 7(5): 411-422.

Elbarkouky, M.E. (2008): The Role of Yeast in Improving the Performance of Male Broiler Chicken Feed Ration Contaminated with Ochratoxin. Egypt. J. of Appl. Sci., 23(2A): 13-24.

Fink-Gremmels, J. (1999): Mycotoxins: their implications for human and animal health. Veterinary Quarterly 21: 115-120.

Girish, C.K. and Smith, T.K. (2008): Effects of Feeding Blends of Grains Naturally Contaminated with Fusarium Mycotoxins on Small Intestinal Morphology of Turkeys. Poult. Sci. 87: 1075-1082.

Henry, R.J. (1964): Clinical chemical, Harper and Row Publisher New York.

Henry, M.H.; Wyatt, and O.J. Fletcher (2000): The Toxicity of Purified Fumonisin B1 in Broiler Chicks. Poultry Science 79: 1378-1384.

Husden, H. and Ropaport, A (1968): Estimation of creatinine. Clin. Chemistry, 14: 222.

James, J. and White, W.L. (1971): Cited in uric acid kits of Bio. Adwic. J. Clin. Chem., 17 (3): 158160.

Javed, T.; Bennett, G.A.; Richard, J.L.; DombrinkKurtzman, M.A.; Cote, L.M. and Buck, W.B. (1993): Mortality in broiler chicks on feed amended with Fusarium proliferatum culture material or with purified fumonisin B1 and moniliforme. Mycopathologia 123: 171-184. 
Jeschke, N.; Nelson, P.E. and Marasas, W.F.O. (1987): Toxicity to ducklings of Fusarium moniliforme isolated from corn intended for use in poultry feed. Poultry Sci. 66: 1619-1623.

Kaplowitz, N.; Fernadez, C.J. and YI, J.R. (1994): Mechanisms of canalicular GSH secretion. Transport in the liver $74^{\text {th }}$ Falk symposium Heideleberg. Germany, 74: 166-177.

Kim-Sh.; Yu-Dj.; Park-Sy.; Lee-Sj. and Ryu-Ks. (2002): Effects of single or mixed feeding of lactobacillus and yeast on performance, nutrient digestibility intestinal micro flora, and fecal NH3 gas emission in laying hens, korean J of Poult. Sci 29: 3, 225-231.

Loiseau, N.; Debrauwer, L.; Sambou, T.; Bouhet, S.; Miller, JD.; Martin, PG.; Viadère, JL.; Pinton, P.; Puel, O.; Pineau, T.; Tulliez, J.; Galtier, P. and Oswald, IP. (2007): (Fumonisin B1 exposure and its selective effect on porcine jejunal segment: sphingolipids, glycolipids and trans-epithelial passage disturbance. Biochem Pharmacol. 30: 74(1):144-52.

Meissonnier, GM.; Laffitte, J.; Loiseau, N.; Benoit, E.; Raymond, I.; Pinton, P.; Cossalter, AM.; Bertin, G.; Oswald, IP. and Galtier P. Selective (2007): Impairment of drugmetabolizing enzymes in pig liver during subchronic dietary exposure to aflatoxin B1. Food Chem Toxicol. Nov; 45(11): 2145-54. Epub Jun 2.

Mohamed, A.O. (2000): Comparative aspects of glutathione (GSH) levels in different of some vertebrate species: is it the related to the Taxonomical position or to environmental adaptations, J. Egypt. Ger. Soc. Zool., 33 Comparative physiology, PP.21-36.

Natt, M.P. and Herrick, C.A. (1952): Anew blood diluents for counting the erythrocytes and leukocytes of chicken. Poultry science, 31: 735-738.

NRC. (1994): Nutrient Requirements of Swine. 10th ed. Natl. Acad. Press, Washington, DC.

O'Brien, E. and Dietrich, D.R. (2005): Ochratoxin A: the continuing engima. Critical Reviews in Toxicology, 35: 33-60.

Ogido, R.; Oliveira, CA.; Ledoux, DR.; Rottinghaus, GE.; Corrêa, B.; Butkeraitis, P.; Reis, TA.; Gonçales, E. and Albuquerque, R. (2004): Effects of prolonged administration of aflatoxin B1 and fumonisin B1 in laying Japanese quail. Poult Sci. Dec.; 83(12): 1953-8.

Park, J.H.; Park, G.H. and Ryu, K.S. (2002): Effect of feeding organic acid mixture and yeast culture on performance and egg quality of laying hens. Korea. J. of Poult. Sci. 29: 2, 109-115

Reitman, S. and Frankel, S. (1957): Colorimetric determination of SGOT and SGPT activity. Amer. J. Clin. Path. (28) 56.

Santin, E.; Paulillo, A.C.; Maiorka, A.; Silva, A.V.F. and Aless, A.C. (2003): Evaluation of cell wall yeast as adsorbent of Ochratoxin in broiler diets. International J. of Poult.Sci. 2: 5 465468.

Sen, C.K. and Packer, L. (1996): Antioxidant and redox regulation of gene transcription. FASEP, J. 10: 709-720.

Sharma, D.R.K. Asrani; Ledoux, D.R.; Jindal, N.; Rottinghaus, G.E. and Gupta, V.K. (2008): Individual and Combined Effects of Fumonisin $\mathrm{B}_{1}$ and Moniliformin on Clinicopathological and Cell-Mediated Immune Response in Japanese Quail. Poult Sci 87: 1039-1051.

Snedecor, G.W and Cochran, W.G. (1982): Statistical Methods. $7^{\text {th }}$ Ed. The Iowa State University. press. Ames. Iowa. U.S.A.

Soliman, A.Z.M. (2003): Bacitracin and active yeast supplementation in layer diets varying in energy content. Egypt. Poult. Sci. 23(1): 3751.

Stanley, VG.; Ojo, R.; Woldesenbet, S. and Hutchinson, DH. (1993): The use of Saccharomyces cerevisiae to suppress the effects of aflatoxicosis in broiler chicks. Poultry Science; 72: 1867-1872.

Tollba, A.A.H.; Sabery, M.M. and Medani, G.G. (2004): Egypt. Poult. Sci.; 24: (11): 333-349.

Wakwak, M.M.; El Afifi, S.F.; Nagla, Soliman, K. and Attia, M. (2003): Effect of adding active dried yeast into Japanese quail diets on performance, some immunity and microbiological aspects. J. Agric. Sci. Mansoura Univ., 28(4); 2601-2612.

Watson, D. (1960): A simple method for the determinaation of serum chololesterol. Clin. Chem. Acta, 5: 637-640.

Weibking, T.; Ledoux, D.R.; Bermudez, A.J.; Turk, J.R. and Rottinghaus, G.E. (1995): Effects on turkey poults of feeding Fusarium moniliforme M -1325 culture material grown under different environmental conditions. Avian Dis. 39: 32-38.

Yildirm, I. and Parlat, S.S. (2003): Effects of dietary addition of live yeast on hatching traits, testis and Ovary weights of Japanese quail in aflatoxicosis. Archiv. Fur Gefluelkund. 67: 5, 208-211. 
$\underline{\text { Assiut Vet. Med. J. Vol. } 59 \text { No. } 137 \text { April } 2013}$

\section{تأثير اضافة ساكارومييسيس سيرفيسى (خميره غير النشطه) على السمان المغذى على علائق ملوثه

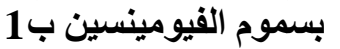

\section{مصطفى ربيع عبل النبى ظليل ، حامد عبد المجيا الامام شلبى ، زغلول أحد عبد المنعم خضر}

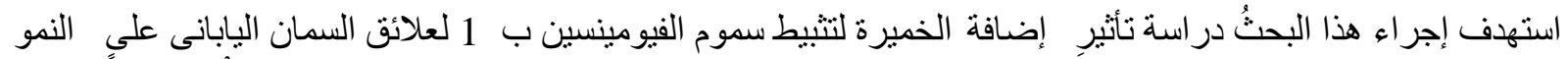

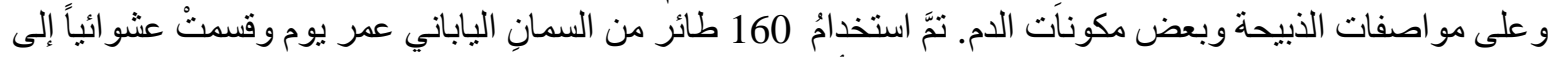

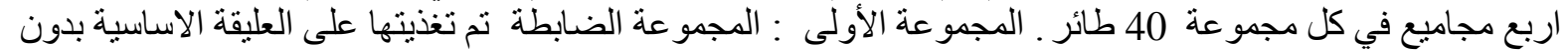

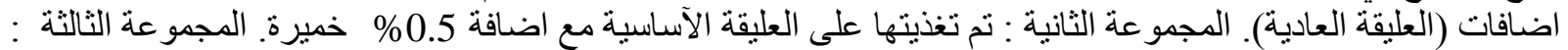

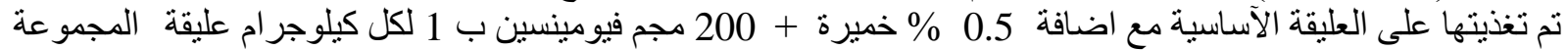

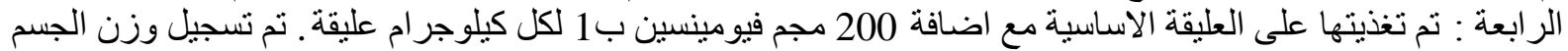

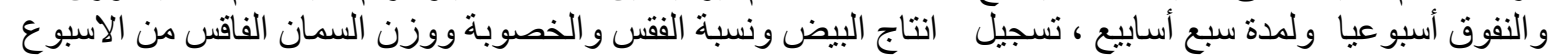

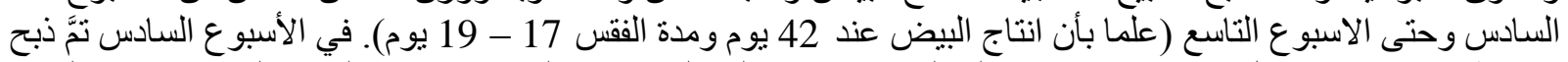

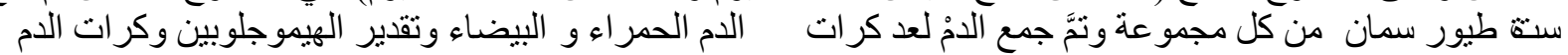

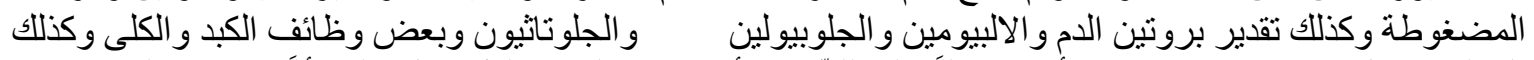

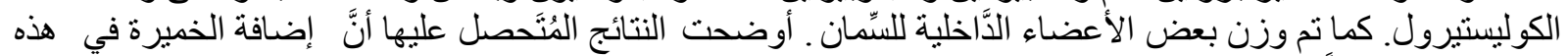

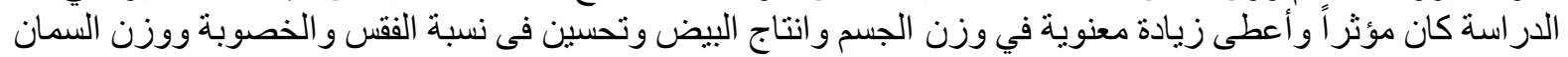

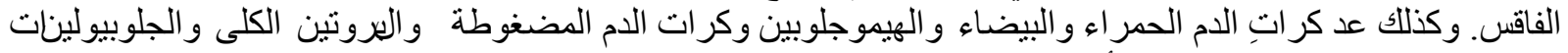
و انخفاض فى النفوق نتيجة تنبيط التأثير ات السامة للفيو مينسين باء النياء 